\title{
Proto-Japonic *e and *o in Eastern Old Japanese Thomas PELLARD
}

In this article I examine the correspondences found between Western Old Japanese high vowels and Eastern Old Japanese midvowels in light of the recent hypotheses concerning the Proto-Japonic vowel system. Correspondences in both the morphology and the lexicon are established and then comparative evidence from several modern Japanese and Ryukyuan dialects is adduced to show that these are instances of retention of Proto-Japonic *e and *o.

Keywords : Eastern Old Japanese, Proto-Japonic, Japanese dialects, Ryukyuan.

Cet article examine les correspondances existant entre les voyelles hautes du japonais ancien de l'Ouest et les voyelles moyennes du japonais ancien de l'Est, à la lumière des récentes hypothèses sur le vocalisme du protojaponique. Des correspondances à la fois dans le lexique et dans la morphologie sont établies, puis des données comparatives de plusieurs dialectes japonais modernes et de langues ryukyu sont fournies pour confirmer qu'il s'agit de cas de rétention des voyelles *e et *o du protojaponique

Mots-clés : japonais ancien de l'Est, proto-japonique, dialectes japonais, langues ryukyu. 


\section{INTRODUCTION}

The Old Japanese (OJ) language of the $7^{\text {th }}$ and $8^{\text {th }}$ centuries is known to us through a collection of mostly poetic texts written in Chinese characters used phonetically. The overwhelming majority of these texts, more than 4000 songs plus some prose, originates from the Yamato plain in Western Japan, where the government of the Yamato state was located. But several texts contain some material written in special varieties of Japanese from the Eastern provinces. These are:

- the Azuma uta (AU), 238 poems in volume XIV of the poetic anthology Man'yōshü (M, completed in 759), presented as poems from the Eastern region (out of which 8 are variants);

- the Sakimori uta (SU), 93 poems in volume XX of the Man 'yōshu, composed by border guards from the Eastern region conscripted to Kyūshū, as well as by their wives;

- the Hitachi Fudoki (HFK), an imperial gazetteer of the Hitachi province, located in Eastern Japan, which contains 9 poems and was written after the imperial decree of 713 .

These texts exhibit some peculiar phonological, grammatical and lexical elements, which can only be explained as dialectal features: most of the OJ texts are written in Western Old Japanese (WOJ), the language of the political center of the Yamato state, while the AU, SU and HFK reflect Eastern Old Japanese (EOJ), a dialect continuum of the Eastern provinces, which correspond to the modern regions of Tōhoku, Kantō and part of Chūbu.

These features are most numerous in the SU, whose authors are clearly identified as coming from the Eastern provinces. On the other hand some of the AU are clearly not written in EOJ but have been in fact composed by dignitaries of the capital sent to the East by the government (Mizushima 1984:221-222). The 9 poems of the HFK contain very few EOJ features and are not a very useful source.

Although comparatively well studied (Fukuda 1965, Hōjō 1966, Mizushima 1984, Mizushima 2005), EOJ data paradoxically 
seem to have been until recently rather underestimated ${ }^{1}$ in the study of the history of the Japonic ${ }^{2}$ language family, long victim of the common prejudice that WOJ is the variety of Japonic closest to the proto-language. But it is clear that EOJ data are essential in many aspects (Antonov 2006, Vovin 2007, Vovin in press). Indeed, as will be demonstrated below, a thorough study reveals that a number of the peculiarities observed are in fact not unique to EOJ but can be found in some modern Japanese dialects and Ryukyuan, a sister branch of Japanese in the Japonic family ${ }^{3}$. They are thus not innovations but archaisms reflecting the proto-language.

The most striking of these features are the cases where we find WOJ high vowels $i_{l}$ and $u$ respectively corresponding to EOJ ${ }^{4}$ midvowels $e_{(1 / 2)}$ and $o_{(1)}$. Similar correspondences are also found between WOJ and Proto-Ryukyuan (PR), which leads us to reconstruct the midvowels $*_{\mathrm{e}}$ and $*_{\mathrm{o}}$ in Proto-Japonic (PJ, first centuries CE). The reconstruction of these vowels is also partially supported by philological evidence (Miyake 2003). A system of at least 6 vowels incorporating $*_{\mathrm{e}}$ and $*_{\mathrm{o}}{ }^{5}$, absent from previous reconstructions based mainly on internal reconstruction of WOJ

\footnotetext{
${ }^{1}$ Notable exceptions are Hōjō (1966), Thorpe (1983), Haggers (2000), and Hino (2003).

${ }^{2}$ Japonic is now a fairly common term including both Japanese and the Ryukyuan languages.

${ }^{3}$ I have modified transcriptions of data from Japanese and Ryukyuan dialects to a more phonetic notation, but without any accentual or tonal marks.

${ }^{4}$ Eastern Old Japanese will be transcribed as Western Old Japanese, with A-type ( $k \bar{o}$-rui) syllables marked with a 1 subscripted after the vowel $\left(i_{1}, e_{1}, o_{1}\right)$, and Btype (otsu-rui) ones with a $2\left(i_{2}, e_{2}, o_{2}\right)$, those without distinctions remaining unmarked $(i, e, o)$, without discussing here the problem of whether EOJ had this distinction (it seems that EOJ did not distinguish between $i_{1}$ and $i_{2}$ or $e_{1}$ and $e_{2}$, but distinguish $o_{I}$ and $o_{2}$; see Fukuda 1965, Mizushima 1984, Mizushima 2005).

${ }^{5}$ Hattori (1978-1979) and Frellesvig \& Whitman (2004) both reconstruct a seventh vowel, respectively $*_{\ddot{\mathrm{u}}}$ and $*_{\mathfrak{i}}$, but for different reasons. Their hypotheses are supported by very few examples and have not received general acceptance.
} 
136

Pellard T. / Cahiers de Linguistique - Asie Orientale 37(2008), 133-158

(Whitman 1990, Martin 1987), is thus now generally accepted for PJ (Hattori 1978-1979, Frellesvig \& Whitman 2008, Vovin in press).

\begin{tabular}{|c|c|c|c|c|}
\hline \multirow[t]{3}{*}{$*_{\mathrm{i}}$} & & & & $*_{\mathrm{u}}$ \\
\hline & $*_{\mathrm{e}}$ & $*_{\partial}$ & $*_{0}$ & \\
\hline & & $*_{\mathrm{a}}$ & & \\
\hline
\end{tabular}

Table 1: PJ vowels

$\mathrm{PJ} *_{\mathrm{e}}$ and $*_{\mathrm{o}}^{\mathrm{o}}$ are thought to have raised to $i_{1}$ and $u$ in WOJ, but some in some cases they may have been preserved as $e_{l}$ and $o_{l}$ :

\begin{tabular}{ccccc}
\hline \hline WOJ & $<$ & PJ & $>$ & PR \\
\hline $\mathrm{i}_{1}$ & $<$ & $*_{\mathrm{i}}$ & $>$ & $*_{\mathrm{i}}$ \\
$\mathrm{i}_{2}$ & $<$ & $*_{\mathrm{ui}}$ & $>$ & $*_{\mathrm{i}}$ \\
$\mathrm{i}_{2}\left(\mathrm{e}_{2}\right)$ & $<$ & $*_{\partial \mathrm{i}}$ & $>$ & $*_{\mathrm{e}}$ \\
$\mathrm{e}_{2}$ & $<$ & $*_{\mathrm{ai}}$ & $>$ & $*_{\mathrm{e}}$ \\
$\mathrm{e}_{1}$ & $<$ & $*_{\mathrm{ia}}$ & $>$ & $*_{\mathrm{e}}$ \\
$\mathrm{e}_{1}$ & $<$ & $*_{\mathrm{i}}$ & $>$ & $*_{\mathrm{e}}$ \\
$\mathrm{i}_{1}\left(\mathrm{e}_{1}\right)$ & $<$ & $*_{\mathrm{e}}$ & $>$ & $*_{\mathrm{e}}$ \\
$\mathrm{u}$ & $<$ & $*_{\mathrm{u}}$ & $>$ & $*_{\mathrm{u}}$ \\
$\mathrm{O}_{1}$ & $<$ & $*_{\mathrm{ua}}$ & $>$ & $*_{\mathrm{o}}$ \\
$\mathrm{O}_{1}$ & $<$ & $*_{\mathrm{au}}$ & $>$ & $*_{\mathrm{o}}$ \\
$\mathrm{u}\left(\mathrm{o}_{1}\right)$ & $<$ & $*_{\mathrm{o}}$ & $>$ & $*_{\mathrm{o}}$ \\
$\mathrm{O}_{2}$ & $<$ & $*_{\partial}$ & $>$ & $*_{\mathrm{o}}$ \\
$\mathrm{a}$ & $<$ & $*_{\mathrm{a}}$ & $>$ & $*_{\mathrm{a}}$ \\
\hline \hline
\end{tabular}

Table 2: Diachronic developments of PJ vowels

Still, Miyake (2003:96-97) remarks that aside from the verbal adnominal suffix (see 2.1.), there are no cases where PR $*_{\mathrm{e}}$ and $*_{\mathrm{o}}$ corresponding to WOJ $i_{1}$ and $u$ are reflected as $e_{1 / 2}$ and $o_{(I)}$ in EOJ. 
This article presents further evidence for the PJ midvowels and their preservation in EOJ.

\section{PROTO-JAPONIC *o}

We can find a fair number of cases where EOJ $o_{(1)}$ corresponds to WOJ $u$. Although they are well known, these correspondences have not yet been clearly shown to be cases of retention from PJ. Comparison with several modern Japanese dialects and with Ryukyuan supports this theory.

\subsection{Adnominal forms of verbs}

OJ has a special inflected form for verbs, traditionally called "adnominal" or "attributive" (Jap. rentaikei), used in relative clauses, in nominalized clauses and in certain focus and interrogative constructions. For adjectives and verbs belonging to certain conjugational classes, it is distinct from the "conclusive" form (Jap. shüshikei) used in main clauses. We find in EOJ as many as 48 adnominal forms marked by a final $-o_{(I)}$ for consonant-base verbs and auxiliaries (20 in the AU, 27 in the SU, 1 in the HFK), whereas in WOJ these verbs and auxiliaries lack the adnominal/conclusive distinction and have a uniform ending in $-u{ }^{6}$ Here is an example of an EOJ adnominal form followed by a conclusive one:

\footnotetext{
${ }^{6}$ The exceptions are for some irregular verbs which have a special conclusive form in $-i$ and an adnominal ending $-u$. We should also note that in Middle Japanese the adnominal and conclusive forms were accentually distinct even when segmentally identical (Martin 1987:191-198).
} 
（1）故奈 乃 思良禰 爾 阿抱 思太毛 $\mathrm{ko}_{1}$ na no $\mathrm{no}_{2}$ sira ne ni ap-o sida mo

Kona GEN white peak LOC meet-ADN time PT

"When [we] meet on the white peak(s) of Kona" (M 14.3478)

（2）佐伎母里爾佐須

$\mathrm{Saki}_{1}$ mori ni sas-u

Sakimori LOC designate-CCL

"[He] assigned me to Sakimori [duty]." (M 20.4382)

We find only two cases of this $-o_{1}$ occurring in other

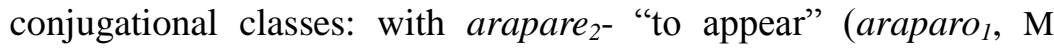
$14.3414)$ and the perfective auxiliary $-n-\left(-n-o_{l}, \mathrm{M} 14.3395\right.$, $14.3480,14.3527,20.4403$ ), which have the adnominal forms araparuru and -nuru in WOJ. These can be explained as having been analogically leveled to a consonant-base in EOJ, a phenomenon well attested in Japanese and Ryukyuan also.

Some of these $-o_{(I)}$ forms are apparently used as conclusive ones, but the same situation is found in WOJ, a phenomenon known as rentai-dome in Japanese. Final adnominal forms are used to denote emphatic mood.

One problem with these special adnominal forms is that although they are too numerous to be considered as accidental misspellings, they are still in a minority: we find many more adnominal forms identical to WOJ than special ones. Nevertheless, one must recall, as mentioned in the introduction, that some of the EOJ poems are in fact written in WOJ, and that also EOJ has been subject to strong influence from WOJ, which led to its eventual and complete obliteration. It is therefore not surprising that we find comparatively so few dialectal features in the EOJ corpus.

The main issue for us here is to determine whether these adnominal forms are innovations or archaisms. I think it is possible to build a solid case for their archaic character by adducing comparative evidence from both modern Japanese dialects (2.1.1.) 
and Ryukyuan (2.1.2.), and also by adding in other examples of the same correspondence not restricted to adnominal forms (2.2.).

\subsubsection{Japanese dialects}

\subsubsection{Hachijō dialects}

The Hachijō and Aogashima dialects are two very closely related dialects spoken on islands $290 \mathrm{~km}$ to the South of Tokyo. Both have an opposition between conclusive forms in /-u/ and adnominal ones in /-o/ for verbs (Hirayama et al. 1965:190-206, Ōshima 1984:254-262):

\begin{tabular}{lll}
\hline \hline Verb & Conclusive & Adnominal \\
\hline "write" & kaku & kako \\
"get out" & dasu & daso \\
"hold" & motsu & moto \\
\hline \hline
\end{tabular}

Table 3: Verb forms in Hachijo dialects.

Here is one example of a conclusive form (3) and one of an adnominal form (4):

(3) uno hito mo kuni: kear-u te:ja that person INCL country.LOC return-CCL HS “Apparently he's going home too.” (Hirayama1965:193)

(4) wa $=g a$ ik-o toki

$\mathrm{I}=\mathrm{NOM}$ go-ADN time

"When I go..." (KKK 1950:208)

\subsubsection{Toshima dialect}

This dialect, spoken in one of the Izu islands between the Izu peninsula and the Hachijō islands, similarly has adnominal forms in 
140

Pellard T. / Cahiers de Linguistique - Asie Orientale 37(2008), 133-158

/-o/, though they are also used as conclusive forms (Ōshima 1984:250-261). But we also find forms in /-u/, followed by an auxiliary, in the precise constructions which historically derive from a conclusive form followed by an auxiliary, as with the conjectural /bei/ (WOJ $b e_{2} k i_{1}$ ) or the negative conjectural /mai/ (Middle Japanese mazi):

(5) $k a z e=g a \quad$ puk-u bei wind $=$ NOM blow-CCL CONJ

"It will (probably) be windy." (Ōshima 1984:265)

It thus seems that, as in other Japanese dialects, adnominal forms have replaced the conclusive ones, but the latter have been preserved in some constructions in this dialect. We can therefore reconstruct an ancient opposition between adnominal forms in $*_{-o}$ and conclusive ones in $*$-u.

\begin{tabular}{lcc}
\hline \hline Verb & Old conclusive & Adnominal \& new conclusive \\
\hline "write" & kaku & kako \\
"get out" & dasu & daso \\
"hit" & butsu & buto \\
\hline \hline
\end{tabular}

Table 4: Verbal forms in Toshima dialect.

It is important to note that the Toshima dialect is not directly related to the Hachijo group, and that these islands are separated by a great distance. Furthermore, there are several other islands whose dialects do not possess similar forms. This consequently excludes that their /-o/ forms could be common innovations or borrowings.

\subsubsection{Akiyama dialect}

The Akiyama dialect, spoken in the mountains between the Niigata and Nagano prefectures, has not been usually brought into 
the discussion of EOJ or PJ adnominal forms, yet it constitutes another piece of independent evidence. Here again we find an opposition adnominal /-o/ vs. conclusive /-u/ (Mase 1992:197-202):

\begin{tabular}{lcc}
\hline \hline Verb & Conclusive & Adnominal \\
\hline "write" & kaku & kako \\
"push" & osu & oso \\
"rise" & tatsu & tato \\
\hline \hline
\end{tabular}

Table 5: Verbal forms in Akiyama dialect.

(6) kotta tfijonoфudzi=ga kats-u-ro:

next.time.TOP Chiyo no fuji=NOM win-CCL-CONJ

"Next time Chiyo no fuji (Sumo wrestler's name) will probably win." (Mase 1992:201)

(7) kat-o $\operatorname{dot} \int a: \quad s o k k \varepsilon=$ no mon da win-ADN time.TOP like.this=GEN thing COP

"It's like that when you win." (Mase 1992:201)

The Akiyama dialect has undergone a lowering of most of its high vowels $*_{\mathrm{i}}$ and $*_{\mathrm{u}}$ to /e/ and /o/, but not after every consonant, and especially not after $/ \mathrm{k} / \mathrm{/} / \mathrm{s} /$ or $/ \mathrm{t} /$. Hence this lowering cannot explain the adnominal forms in /-o/. Analogy with verbs whose base-consonant has not prevented the lowering of $* u$ to /o/ cannot explain it either: why would verbs have had their ending lowered to /-o/ in adnominal function but not in conclusive function? It is more reasonable to consider the $/-\mathrm{o} /$ in these adnominal forms as original.

\subsubsection{Ryukyuan}

Thorpe (1983:182-183) reconstructs a PR suffix * $*_{-o}$ for attributive (here called adnominal) and emphatic mood, which also appears before prohibitive, achievement, interrogative, adversative 
and concessive markers, but he does not discuss the comparative evidence underlying his reconstruction at length.

Indeed one can find in most Northern Ryukyuan dialects (Amami and Okinawa) a fossilized adnominal form appearing only before some formal nouns ${ }^{7}$ and suffixes. It is felt as archaic by speakers (Uchima 1997:34) and is usually not used anymore as a true adnominal form, except in some traditional songs (Matsumoto 1998:199). Contrary to the actual adnominal and conclusive forms, this form does not originate from a compound with the stative verb "to be".

For example, in the Northern Okinawan dialect of Nakijin Yonamine, this form is found among others before the formal nouns [?mjo:dui] ("interval", "while"), [ha:di] ("expectation", "ought to"), [khadiri] ("limit", "as much as"), the terminative suffixes [madi:], [gadi:], [jak ${ }^{2} \mathrm{i}$ ], or the restrictive suffix [ $\mathrm{bik}^{2} \mathrm{e}:$, and even as a main clause predicate when the adverb [Goi] ("very") is used in the sentence (Nakasone 1987:155):

(8) wa:=ga hak ${ }^{2}-\mathrm{u}$ Pmjo:dui matt $\int^{2} u r e:$

I-NOM write-ADN while wait.IMP

"Wait while [I] write [it]."

(9) $w a:=g a h^{2}{ }^{2}-u$ madi: matt ${ }^{2} u r e:$

$\mathrm{I}=\mathrm{NOM}$ write-ADN until wait.IMP

"Wait until [I] write [it]."

(10) Pari(:) gande: goi hak ${ }^{2}-\mathrm{u}$

he AMBIG very write-ADN

"He writes very well."

These forms can be reconstructed with a final $*_{-}$, directly attached to the root of consonant-base verbs. For instance, the

\footnotetext{
${ }^{7}$ Formal nouns are nouns which are used as function words in some grammatical constructions.
} 
Proto-Japonic *e and *o in Eastern Old Japanese / CLAO 37(2008) 133-158

obsolete adnominal form of $t$-base verbs (/mat-/ "to wait", /tat-/ "to stand") has its final syllable corresponding to WOJ $t o_{(1 / 2)}$ and not $t u$.

\begin{tabular}{|c|c|c|c|c|c|}
\hline Dialect & ADN & with & person $^{8}$ & one & when \\
\hline WOJ & tatu, matu & $\mathrm{to}_{2}$ & $\mathrm{pi}_{1} \mathrm{to}_{2}$ & $\mathrm{pi}_{1} \mathrm{to}_{2} \mathrm{tu}$ & itu \\
\hline Chabana ${ }^{9}$ & matu & tu & pitfu & ti:tsi & Pitfi \\
\hline Yonamine $^{10}$ & $\operatorname{tat}^{2} u$ & $t^{2} u$ & $t \int^{2} \mathrm{u}$ & $t^{2} \mathrm{it} \int^{\mathrm{i}} \mathrm{i}$ & hit ${ }^{2} \mathrm{i}:$ \\
\hline Naha-Shuri ${ }^{11}$ & tatu & tu & $\mathrm{tt} \int \mathrm{u}$ & ti:tsi & Pitsi \\
\hline PR & *tato, *mato & *to & *pito & piteetu & *etu \\
\hline
\end{tabular}

Table 6: Ryukyuan adnominal forms

In Southern Ryukyuan (Sakishima, e.g. Miyako, Yaeyama and Yonaguni), the situation is more complicated, and the forms which appear at first sight to correspond to $*_{-o}$ (in Yonaguni or Hatoma for example) should better not be taken at face value. The diachronic developments of the verbal morphology in Ryukyuan are a complicated matter, and the reconstruction of the Proto-Sakishima verbal system is particularly problematic because of some contradictory correspondences. This would require a separate treatment, which is far beyond the scope of this article ${ }^{12}$.

\subsubsection{Conclusion on adnominal forms of verbs}

Adnominal forms with a final /-o/ or reconstructible with an $*_{-o}$ are thus attested in several different (sub-)branches of the

\footnotetext{
${ }^{8}$ The / $t /$ in the last syllable of "person" has undergone regular progressive palatalization in many of dialects.

${ }^{9}$ Nakama (1992), Hattori et al. (1959).

${ }^{10}$ Nakasone (1987), Hattori et al. (1959).

${ }^{11}$ For more details on this problem, see Kokuritsu Kokugo Kenkyūjo (1963), Nohara (1976).

${ }^{12}$ See on this matter Thorpe (1983), Uchima (1984), Nakama (1992), Karimata (1999).
} 
144

Pellard T. / Cahiers de Linguistique - Asie Orientale 37(2008), 133-158

Japonic family (EOJ, Hachijō, Toshima, Akiyama and Ryukyuan). Hence this excludes the possibility that these forms are a common innovation. The geographic distribution, with several attestations in very distant and isolated areas, also excludes the possibility of borrowing.

Whitman (1990:538-540) has proposed to explain EOJ's adnominal $-o$ as a lowering of $*$-uwu $<*$-u-ru, but evidence for such a development in EOJ is scarce. It would also imply that EOJ and PR both underwent the same innovation, which is not realistic. Hayata (2000) considers the EOJ $-o_{(1)}$ to have a diphthongal origin and reconstructs the PJ adnominal ending as *-rua. But if *ua indeed develops into Old Japanese $o_{1}$, it does not raise to $u$ in WOJ (cf. kazu-ape $2_{2^{-}}$"number-assemble" > kazo pe $_{2^{-}}$"to count"). We would thus expect adnominal forms in $-o_{I}$ in WOJ too.

We can also add as further evidence the interesting inscription found on the Inariyama burial mound sword (471? 531?), also partially attested in the Eta Funayama burial mound inscription $\left(5^{\text {th }} \mathrm{c}\right.$.). It may be interpreted as having an adnominal $-o$ following the verb take $_{1^{-}}$"to be tall, great" (Miyake 2003:122):

Later Han

$$
\begin{aligned}
& \begin{array}{lllll}
\text { 蒦 } & \text { 加 } & \text { 多 } & \text { 支 } & \text { 卤 } \\
\text { *yuək } & * \text { ka } & * \text { tai }>* \text { ta } & * \text { kie>*cie } & * \text { la? } *^{\prime} \text { lo? }
\end{array} \\
& * \text { hwek } * \text { kæ } * \text { ta } * \text { ciə } \quad * \text { lo? } \\
& \text { waka-take }_{1} r u \text { "(the one who is) young and }
\end{aligned}
$$$$
\text { Early Middle }
$$$$
\text { Chinese }
$$$$
\text { WOJ }
$$

Therefore it seems rather unlikely that the adnominal forms arose late in Japonic, as proposed by Frellesvig (2008), since there is definitely evidence for reconstructing the adnominal/conclusive opposition in PJ from comparative evidence. 


\subsection{Lexical examples}

We find also some lexical examples exhibiting the same correspondence WOJ $u::$ EOJ $o_{(l)}$ and for which we can tentatively reconstruct $\mathrm{PJ} *_{0}$.

The toponym To $_{2}$ pe $_{2}$ tapomi $_{1}$ (M 20.4324, WOJ Töpotapumî "Tōtōmi") seems to be derived from *to ${ }_{2}$ po-tu-apa-umi ${ }_{1}$ "distantGEN-fresh-sea" (Ōno et al. 1974). I propose below several pieces of original evidence that point to a reconstruction of $\mathrm{PJ} *$ omi rather than *umi for "sea"13, which would agree with the EOJ $-o m i_{1}$ in $\mathrm{To}_{2} \mathrm{pe}_{2}$ tapomi $_{1}$. First, most of WOJ words beginning with um- are attested also spelled as mum- in WOJ or Middle Japanese, but umi "sea" is not:

\begin{tabular}{llll}
\hline \hline uma & $\sim$ muma & "horse" \\
umago & $\sim$ mumago & "grand-child" \\
uma- & $\sim$ muma- & "good" \\
umare- & $\sim$ mumare- & "to be born" \\
ume & $\sim$ mume & "plum" \\
\hline \hline
\end{tabular}

Table 7: WOJ and MJ um- mum- alternations.

Second, though Thorpe (1983:325) is unable to decide whether PR "sea" was *umi or *omi, I believe it is possible to reconstruct an initial *o here. In Thorpe's reconstruction, PR initial $*_{\mathrm{o}}$ and $*_{\mathrm{u}}$ seem to have generally merged, but a closer look at the data reveals that certain dialects have in some cases different reflexes. For instance whereas Yoron uniformly has an initial /u-/ in the words below, other dialects have /(P)u-/ only for some of them:

\footnotetext{
${ }^{13}$ An anonymous reviewer has informed me that such a reconstruction has already been suggested by Leon Serafim, but his hypothesis unfortunately still remains unpublished.
} 
146

Pellard T. / Cahiers de Linguistique - Asie Orientale 37(2008), 133-158

\begin{tabular}{|c|c|c|c|c|c|c|}
\hline Dialect & be born & grand-child & horse & sea & pus & think \\
\hline Yoron $^{14}$ & unurjun & umaga & uma & umi & unt $\int u$ : & umujuy \\
\hline Nakijin ${ }^{15}$ & Pma:rin & Pma:ga & ?ma: & Pumi & Pumi: & Pumin \\
\hline Ishigaki $^{16}$ & mari- & ma:фа: & Pmma & ?umï & Punku & Pumo:y \\
\hline Yonaguni $^{17}$ & ma:ruy & ma:yu & $\mathrm{mma}$ & unnaga & untu & umuy \\
\hline $\begin{array}{l}\text { New PR } \\
\text { reconstruction }\end{array}$ & *umare- & *umag $[a, o]$ & *uma & $*_{\text {omi }}$ & *omi & *omow- \\
\hline
\end{tabular}

Table 8: PR *um- and *om-

On this basis I propose the following amendment to Thorpe's $P R$ reconstruction:

\begin{tabular}{lll}
\hline \hline $\mathrm{PR}$ & & Modern Ryukyuan dialects \\
\hline$*_{\mathrm{u}}$ & $>$ & $(\mathrm{P}) \mathrm{m} \sim \varnothing / \#$ / \\
$*_{\mathrm{o}}$ & $>$ & $(\mathrm{P}) \mathrm{u} / \# \_\mathrm{m}$ \\
\hline \hline
\end{tabular}

Table 9: Diachronic developments of PR *om- and *um-

In most Ryukyuan dialects the word for "sea" has an initial $/(\mathrm{P}) \mathrm{u}-\mathrm{I}^{18}$, and should be therefore reconstructed as PR *omi < PJ *omi.

The word "snow" is attested as $\mathrm{yo}_{2} k i_{1}$ in EOJ (M 20.3423) and corresponds to WOJ $y u k i_{1}$. While we usually find an EOJ $o_{I}$ corresponding to WOJ $u$, we have here a problematic case of $o_{2}$, but we should note that this is an AU poem, and it may thus have been corrupted by the scribes of WOJ. We can find similar forms with an

\footnotetext{
${ }^{14}$ Nakamatsu (1999), Nakama (1992).

${ }^{15}$ OGKS (1999-2003).

${ }^{16}$ Miyagi et al. (2002).

${ }^{17}$ Hirayama \& Nakamato (1964), HDOBK (1986).

${ }^{18}$ In most Southern Ryukyuan dialects, the expected initial /u-/ in "sea" has fronted to /i-/ (ex: Miyako /im/). Thorpe (1983:45) states that this development is regular: initial *u or $*_{o}$ is fronted to $*_{i}$ before a "syllabic" consonant.
} 
$o$ in several modern Japanese dialects located in the following prefectures (Tokugawa et al. 1989, Hirayama et al. 1992-1994): Aomori, Yamagata [jogï], Niigata, Sado, Nagano [joki]). In Ryukyuan, the cognates of WOJ $y u k i_{1}$ usually mean not "snow" but "hail", and no modern dialect seems to have retained a distinction between PJ $*$ ju and $*$ jo or $*$ jo. Still, in the Old Okinawan poetic anthology Omoro Sōshi, believed to contain a number of spellings reflecting a stage before the raising of PR $*_{e}$ and $*_{\mathrm{o}}$ (Vovin 2005: xix), the word "snow/hail" is found spelled only once as yuki (poem \#583) and 15 times as yoki (poems \#39, 100, 490, 514, 514, 583, $672,672,1000,1085,1085,1086,1287,1511,1511)$. This may thus imply that "snow/hail" had a midvowel *o rather than *u.

The form wosagi $_{1}$ (M 14.3529) for WOJ usagi "hare, rabbit" is paralleled by some modern Japanese dialects which have an initial $o$ - in this word: Kawabe [osani], Toyama [ofani], Wakayama [osagi], Gokosan [osagi] (Tokugawa et al. 1989, Hirayama et al. 1992-1994). Furthermore, the transcriptions of Koguryo toponyms in the Samkwuk saki (1145), which record a language in all likelihood related to Japanese in someway, contain the word "hare" transcribed as 烏斯含, which can be reconstructed in Early Middle Chinese as *o siă yəm (Pulleyblank 1991).

We also find other cases of the correspondence EOJ $o_{(I)}::$ WOJ $u$, but we lack comparative evidence to confirm that they are instances of retention of $\mathrm{PJ} *_{0}$. This is the case for ayapo- (M 14.3539, WOJ ayapu- "dangerous"), no ${ }_{1}$ re- (M 20.4351, WOJ nure"sleep"), popom- (M 20.4387, WOJ pupum- "to be unopened"), ayo $_{1}$ k- (M 20.4390, WOJ ayuk- "shake") and -to to $_{2}$ (M 20.4421, WOJ -tutu "continuative suffix", problematic since EOJ has an $o_{2}$ here).

We also find a doublet form tayura (M 14.3392) tayo $_{1} r a(\mathrm{M}$ 14.3368) "agitated" with $o_{1} \sim u$ for a word not attested in WOJ. This could reflect the coexistence of a pre-raising and a post-raising form (possibly in different dialects, though both poems are from the Shimōsa province). 
148

Pellard T. / Cahiers de Linguistique - Asie Orientale 37(2008), 133-158

Finally there is the problematic $s e m i_{1} d o_{1}$ (M 14.3546, WOJ si$m i_{1} d u$ "fresh water") which does not match the PJ reconstruction *mentu for "water", expected from PR *mezu (Thorpe 1983:345):: WOJ $m i_{1} d u$. Indeed the Ryukyuan evidence clearly points to a final $*_{-\mathrm{u}}$ and not $*_{-\mathrm{o}}$ (and also to a medial $*_{\mathrm{e}}$ not $*_{\mathrm{i}}$ ).

\section{PROTO-JAPONIC *e}

Parallel to EOJ $o_{(I)}::$ WOJ $u$, we find cases of EOJ $e_{(1 / 2)}$ corresponding to WOJ $i_{1}$. In the same way, these can be shown to be retentions of $\mathrm{PJ} *$ e, with adnominal forms as the main bulk of evidence.

\subsection{Adnominal forms of adjectives}

Adjectives have a special adnominal form too, marked by $-k i_{1}$ in WOJ, and we find a corresponding marker $-k e_{1 / 2}$ in EOJ attested 18 times (10 times in $\mathrm{AU}, 8$ times in $\mathrm{SU}$ ):

（12）阿志氣 比等 奈里

asi-ke ${ }_{2} \quad \mathrm{pi}_{1} \mathrm{to}_{2} \quad$ nar-i

bad-ADN person be-CCL

"[He] is a bad person."

(M 20.4382)

But first it must be noted that we can find a few occurrences of the adnominal marker $-k e_{1}$ in WOJ. One example is found in the Kojiki, known for its archaic features like the $\mathrm{mo}_{l} / \mathrm{mo}_{2}$ distinction lost in most of the later texts ${ }^{19}$ :

\footnotetext{
${ }^{19}$ See Bentley (2002) for a discussion of the $m o_{1} / m o_{2}$ distinction in the Man'yōshu.
} 
(13) 波斯祁 夜 斯

pasi-ke $_{1}$ ya si

dear-ADN EMPH EMPH

"How dear it is..." (Kojiki 33)

The same form pasi-ke $e_{1}$ is also found in M 15.3691 and $\mathrm{M}$ 15.3692, but the usual adnominal form of this adjective is pasi-ki $i_{1}$, which is attested in the same construction as above (pasi-ki $i_{1}$ yasi, $\mathrm{M}$ 7.1358, M 8.1619). The form with $-k e_{1}$ is thus neither a hapax legomenon nor a scribal error, but can be explained as the preservation of a pre-raising archaic form.

Moreover, here again some modern Japanese dialects preserve this marker, and these are not a random collection of dialects: the dialects having /-ke/ all happen to also preserve the adnominal verbal suffix /-o/.

Thus adnominal forms in /-ke/ are attested in the Hachijō dialect (Hirayama et al. 1965:195-196, Ōshima 1984:259, 262):

\begin{tabular}{ll}
\hline \hline Adjective & Adnominal \\
\hline "high" & takake \\
"bad" & waruke \\
"good" & joke \\
\hline \hline
\end{tabular}

Table 10: Adjectival forms in Hachijō dialect

(14) taka-ke jama

high-ADN mountain

"A high mountain" (Ōshima 1984:262)

The Akiyama dialect also has a distinction between conclusive and adnominal forms of adjectives, the latter ones being marked by /-(k)ke/ (Mase 1992:205-207) : 
Pellard T. / Cahiers de Linguistique - Asie Orientale 37(2008), 133-158

\begin{tabular}{lll}
\hline \hline Adjective & Conclusive & Adnominal \\
\hline "happy" & ore fi: & orefike \\
"good" & e: & eke \\
"red" & ake: & akakke \\
\hline \hline
\end{tabular}

Table 11: Adjectival forms in Akiyama dialect

(15) satjo non-de aka-kke tsuro ji-ter-o na alcohol.ACC drink-SEQ red-ADN face.ACC do-DUR-CCL EXCL "[You] have drunk alcohol and your face is red." (Mase 1992:206)

(16) atama-kke $=\mathrm{ga}$ Jire:

head-hair=NOM white.CCL

"[His] hair is white." (Mase 1992:206)

Although in this dialect most of the $*_{\mathrm{i}}$ have lowered to /e/, this /-ke/ is not explainable as a lowering of $*$-ki, since WOJ $k i_{1 / 2}$ corresponds to a palatalized /t $\mathrm{j}$ i/ in Akiyama (Mase 1992:61-89):

\begin{tabular}{llll}
\hline \hline Word & WOJ & $:$ Akiyama \\
\hline "time" & $\mathrm{to}_{2} \mathrm{ki}_{1}$ & tot $\mathrm{i}$ \\
"fog" & $\mathrm{ki}_{2} \mathrm{ri}$ & t $\mathrm{ire}$ \\
"tree" & $\mathrm{ki}_{2}$ & $\mathrm{t} \mathrm{j}$ \\
"breath" & $\mathrm{iki}_{1}$ & et $\mathrm{i}$ \\
\hline \hline
\end{tabular}

Table 12: WOJ $k i_{1 / 2}::$ Akiyama t $\mathrm{i}$

We can thus assume this suffix goes back to PJ *-ke. Nonetheless, the conclusive forms like [ake:] must come from *aka$\mathrm{i}$, and this $*_{-\mathrm{i}}$ must in turn be a lenition of adnominal $*$-ki, as happened in other Japanese dialects ${ }^{20}$. At present I can only propose

${ }^{20}$ I would like to thank Bjarke Frellesvig for having pointed this out to me. 
that these forms are due to the influence of surrounding dialects and Standard Japanese.

Unfortunately there is no Ryukyuan evidence in this case, since Ryukyuan has an adjectival morphology in most parts different from Japanese. According to Hirayama \& Nakamoto (1964), there is a marker corresponding to the WOJ $-b e_{2} k i_{1}$ in some Ryukuan dialects, the adnominal form of a debitive/conjectural marker inflected like adjectives. This is in all likelihood a recent loan from Japanese, the correspondences between Ryukyuan dialects being highly irregular.

Martin (1987:812), who generally rejects the existence of PJ $*_{\mathrm{e}}$ and $*_{\mathrm{o}}$, has argued that EOJ $-k e_{1 / 2}$ and WOJ $-k i_{1}$ are contractions of $-k u$ ari, the adverbial ending of adjectives followed by the verb "to be":

(17) - ku ari $>$-kai $>$ EOJ -ke

$$
>-\mathrm{ki}>\text { WOJ }-\mathrm{ki}_{1}
$$

There are several problems which make this proposal unacceptable. First, this construction would be very odd as the origin of the adnominal ending, since the form ari is an infinitive and conclusive form, but not an adnominal form (the adnominal form of this verb is $a r u)$. Second, the construction $-k u$ ar- is indeed attested in OJ, and we also find the contracted form -kar-. Both survive in later Japanese and some dialects ${ }^{21}$. It is thus improbable that there was yet a third, completely fused, version of this construction, restricted to adnominal function.

Thus, although the evidence is less impressive than for $-o$, it is possible to make a case for the archaic nature of the adjectival adnominal suffix $-k e$. However the question of whether it existed in

\footnotetext{
${ }^{21}$ It is even attested in most dialects of Miyako Ryukyuan: -kaz -ka: (data from my own fieldwork).
} 
152

Pellard T. / Cahiers de Linguistique - Asie Orientale 37(2008), 133-158

PJ is still open, as we lack Ryukyuan evidence for it, so we can only reconstruct it for Proto-Japanese, not Proto-Japonic.

\subsection{Lexical examples}

For the following examples there exists no standard PJ reconstruction, nor do we find straightforward comparative evidence. We can only suppose that they may be instances of PJ *e:

\begin{tabular}{lclll}
\hline \hline EOJ & $::$ & WOJ & Gloss & Reference \\
\hline sawesawe & $::$ & sawisawi & onomatopoeia & (M 14.3481) \\
sake $_{2}$ ku & $::$ & saki ku & "safely, happily" & (M 20.4368) \\
sake $_{1}$ ku & $::$ & saki ku & "safely, happily" & (M 20.4372 \\
ke $_{1}$ nite & $::$ & ki ${ }_{1}$ nite & "having come" & (M 20.4337) \\
\hline \hline
\end{tabular}

Table 13: EOJ $e_{1 / 2}::$ WOJ $i_{l}$

The word utikape ("seam", M 14.3482) is not attested in WOJ, but we find a form utikapi $i_{1}$ in a variant of this poem (3482'), possibly reflecting a post-raising form.

\section{CONCLUSION}

In this article I have established the correspondences Western Old Japanese $i_{1}::$ Eastern Old Japanese $e_{(1 / 2)}$ and WOJ $u::$ EOJ $o_{(1)}$ and given comparative evidence from three independent Japanese dialects (Hachijō, Toshima, Akiyama), also from Ryukyuan, in both the lexicon and the morphology, to support the view that these are cases of retention of Proto-Japonic *e and *o. Based on this, I have proposed several Proto-Japonic reconstructions, most notably the verbal adnominal ending ${ }^{22} *_{-o}$ and the adjectival adnominal ending

${ }^{22}$ This reconstruction is for consonant-base verbs only and makes use of only the comparative method. 
*-ke. These constitute further evidence for the Proto-Japonic 6 vowels hypothesis. I also suggested an improvement to Thorpe's Proto-Ryukyuan reconstruction and showed that PR distinguished initial $*_{\mathrm{u}}$ and $*_{\mathrm{o}}$ before $*_{\mathrm{m}}$.

Proto-Japonic *e and $*_{0}$ are best preserved in the morphology of both Eastern Old Japanese and Japanese dialects. Certainly the influence of Western Old Japanese and its successor Middle Japanese, which had lost $\mathrm{PJ} * \mathrm{e}$ and $* \mathrm{o}$, played a great part in the quasi-total elimination of these vowels in Eastern Old Japanese and peripheral Japanese dialects. Contamination by Western Old Japanese also explains why we find more raised forms than forms having preserved the midvowels. This situation can be interpreted as a typical case of an innovation spreading from a center (WOJ) and failing to affect the dialects located at the periphery or in isolated areas.

Unfortunately, the limitations of the Eastern Old Japanese corpus, along with the fact of contamination by Western Old Japanese, prevent us from grasping the whole details of its special features, both archaic and innovative. We should also bear in mind that Eastern Old Japanese was not a monolithic language, but a group of dialects spoken over a large area. A detailed study of the geographical distribution of these features indeed reveals several distinct areas influenced at different degrees by Western Old Japanese (Hino 2003).

Although Eastern Old Japanese data should be recognized and used as an important source for the study of the history of the Japonic language family, the nature and the size of the corpus hardly make it usable as a primary source. We should always try to find other comparative evidence before taking Eastern Old Japanese at face value. This is the principle which has been applied in the present analysis. 


\section{REFERENCES}

ANTONOV Anton (2006). Le japonais et le coréen : une famille impossible ? Paper presented at the conference La linguistique comparée en France aujourd 'hui, EHESS, Paris, $4^{\text {th }}$ of March.

BENTLEY John R. (2002). The spelling of /mo/ in Old Japanese. Journal of East Asian Linguistics, 11(4), pp. 349-374.

FRELLESVIG Bjarke (2008). On reconstruction of Proto-Japanese and preOld Japanese verb inflection. In FRELLESVIG B. \& WHITMAN J. B. (eds.), Proto-Japanese, Amsterdam : John Benjamins, pp. 179-198.

Frellesvig Bjarke \& WhitMAN John B. (2008). Evidence for seven vowels in Proto-Japanese. In : FRELlesviG B. \& WhitMAn J. B. (eds.), Proto-Japanese, Amsterdam : John Benjamins, pp. 15-41.

FUKUDA Yoshisuke (1965). Nara jidai tōgoku hōgen no kenkyū [A study on the Eastern dialects of the Nara period]. Tokyo : Kazama shobō.

HAGERS Steven (2000). The attributive and conclusive forms of modern Japanese and Ryukyuan dialects in a historical perspective. Studia Etymologia Cracoviensia, 5, pp. 13-42.

HATTORI Shirō (1978-1979). Nihon sogo ni tsuite (1-22) [On ProtoJaponic]. Gengo, 7(1)-7(3), 7(6) - 8(12).

HATTORI Shirō, UEMURA Yukio \& ToKUGAWA Munemasa (1959). Amami shotō shohōgen no gengo nendaigakuteki chōsa [A glottochronological survey of the dialects of the Amami islands]. In KYŪGAKKAI RENGō (ed.), Amami: Shizen to bunka, Tokyo : Nihon gakujutsu shinkōkai, pp. 433-464.

HAYATA Teruhiro (2000). The liquid and stem-final vowel alternations of Verbs in Ancient Japanese. Gengo Kenkyū, 118, pp. 5-27. 
Proto-Japonic *e and *o in Eastern Old Japanese / CLAO 37(2008) 133-158

HINO Sukenari (2003). Nihon sogo no boin taikei — Jōdai tōgoku hōgen shiryō ni yoru saikō [The vowel system of Proto-Japonic - a reconstruction based on Eastern Old Japanese data]. In Vovin A. \& OsADA T., Nihongo keitōron no genzai, Kyōto : Kokusai Nihon bunka kenkyū sentā, pp. 187-206.

HIRAYAMA Teruo (ed.). (1965). Izu shotō hōgen no sōgōteki kenkyū [A general study of the Izu islands dialects]. Tokyo : Meiji shoin.

HIRAYAMA Teruo \& NAKAMOTO Masachie (1964). Ryūkyū Yonaguni hōgen no kenkyū [A study of Yonaguni Ryukyuan]. Tokyo : Tōkyōdō.

HIRAYAMA Teruo et al. (eds.) (1992-1994). Gendai nihongo hōgen daijiten [Dictionary of modern Japanese dialects]. Tokyo : Meiji shoin.

HōJō Tadao (1966). Jōdai Azuma hōgen no kenkyū [Study of the Eastern Old Japanese dialect]. Tokyo : Nihon gakujutsu sinkōkai.

HŌSEI DAIGAKU OKINAWA BUNKA KENKYŪJO (HDOBK) (1986). Ryūkyū no hōgen - Yaeyama Yonaguni-jima [Ryukyuan dialects - Yaeyama Yonaguni]. Vol. 11.

KARIMATA Shigehisa (1999). Miyako shohōgen no "shūshikei" no seiritsu ni tsuite [On the origin of the conclusive form of the Miyako dialects]. Nihon tōyō bunka ron shū, 5, pp. 27-51.

KoKURITSU KOKUGO KeNKYŪJO (KKK) (ed.) (1950). Hachijō-jima no gengo chōsa [Linguistic survey of the Hachijō island]. Tokyo : Shūei shuppan.

KoKURITSU KOKUGO KeNKYŪJO (KKK) (ed.) (1963). Okinawago jiten [Dictionary of the Okinawan language]. Tokyo : Ōkurashō Insatsukyoku.

MARTIN Samuel E. (1987). The Japanese language through time. New Haven/London : Yale University Press. 
156

Pellard T. / Cahiers de Linguistique - Asie Orientale 37(2008), 133-158

MASE Yoshio. Nagano-ken shi - Hōgen hen [History of the Nagano prefecture — Dialect volume]. Nagano : Nagano-ken shi kankōkai.

Matsumoto Hirotake (1998). Shodon hōgen no dōshi no hi-shūshi kei oboegaki [Note on the non-conclusive form of verbs in the Shodon dialect]. In : Tōkyō daigaku (ed.), Tōkyō daigaku kokugo kenkyūshitsu sōsetsu hyaku shünen kinen kokugo ronshū, Tokyo : Kyūko shoin, pp. 199-213.

MiYAKe Marc H. (2003). Philological evidence for *e and *o in Pre-Old Japanese. Diachronica, 20, pp. 81-136.

MiYagi Shin'yū, KaJIKU Shin'ichi, Hateruma Eikichi \& NishioKA Satoshi (eds.) (2002). Ishigaki hōgen goi ichiran [Vocabulary list of the Ishigaki dialect]. Suita : Ōsaka gakuin daigaku jōhō gakubu.

MizuSHIMA Yoshiharu (1984). Man'yōshū Azuma uta no kokugogakuteki kenkyū [Linguistic study of the Azuma uta of the Man'yōshū]. Tokyo : Kasama shoin.

Mizushima Yoshiharu (2005). Man'yōshū Sakimori uta no kokugogakuteki kenky $\bar{u}$ [Linguistic study of the Sakimori uta of the Man'yōshū]. Tokyo : Kasama shoin.

NAKAMA Mitsunari (1992). Ryūkyū hōgen no kosō [The old layer of the Ryukyuan dialects]. Tokyo : Daiichi shobō.

NAKAMATSU Takeo (1999). Ryūkyūgo jiten [Dictionary of the Ryukyuan languages]. Naha : Genken shuppan.

NAKASONE Seizen (1987). Ryūkyū hōgen no kenkyū [Study on the Ryukyuan dialects]. Tokyo : Shinsen sha.

NOHARA Mitsuyoshi (1976). Okinawa Naha hōgen dōshi no katsuyō [Conjugations of the verbs of the Naha dialect of Okinawa]. Okinawa kokusai daigaku bungaku bun kiyō kokubungaku hen. 4(2), pp. 29-41. 
OKINAWA GENGO KENKYŪ SENTĀ (OGKS) (1999-2003). Nakijin hōgen onsei dēta bēsu [Phonetic database of the Nakijin dialect]. http://ryukyu-lang.lib.u-ryukyu.ac.jp/nkjn/

ŌNO Susumu, SATAKE Akihiro \& MAEDA Kingorō (eds.) (1974). Iwanami kogo jiten [A dictionary of Pre-modern Japanese]. Tokyo : Iwanami shoten.

ŌSHIMA Ichirō (1984). Izu shotō no hōgen [Dialects of the Izu islands]. In : IITOYO Kiichi et al. (eds), Kōza hōgengaku 5 - Kantō no hōgen. Tokyo: Kokushokankōkai, pp. 233-271.

PULLEYBLANK Edwin G. (1991). Lexicon of reconstructed pronunciation in Early Middle Chinese, Late Middle Chinese and Early Mandarin. Vancouver : University of British Columbia Press.

THORPE Maner L. (1983). Ryūkyūan language history. Ph.D. dissertation, University of Southern California.

TOKUGAWA Munemasa et al. (eds.) (1989). Nihon hōgen daijiten [Dictionary of Japanese dialects]. Tokyo : Shogakukan, 3 vols.

UCHIMA Chokujin (1984). Ryūkyū hōgen bunpō no kenkyū [Study on the grammar of Ryukyuan dialects]. Tokyo : Kasama shoin.

UCHIMA Chokujin et al. (ed.) (1997). Okinawa-ken no kotoba (Kita$R y \bar{u} k y \bar{u}$ ) [The language of the Okinawa prefecture (Northern Ryukyu)]. Tokyo : Meiji shoin.

Vovin Alexander (2005). A descriptive and comparative grammar of Western Old Japanese; Part 1: Sources, script and phonology, lexicon, nominals. Folkestone : Global Oriental.

Vovin Alexander (2007). Once again on doublets in Western Old Japanese. In : Frellesvig, B., ShiBATANi, M. \& SMith, C. J. (eds.), Current issues in the history and structure of Japanese, Tokyo : Kuroshio shuppan, pp. 351-373. 
158

Pellard T. / Cahiers de Linguistique - Asie Orientale 37(2008), 133-158

Vovin Alexander (in press). Koreo-Japonica: A re-evaluation of a common genetic origin. University of Hawai'i Press.

WhitMAN John B. (1990). A rule of medial *-r- loss in pre-Old Japanese. In : BALDI P. (ed.), Linguistic Change and Reconstructive Methodology, Berlin \& New York : Walter de Gruyter, pp 511-545.

\author{
Thomas PELLARD \\ CRLAO-EHESS \\ 54, Bd Raspail \\ 75006 Paris \\ FRANCE \\ thomas.pellard@gmail.com
}

